J OURNAL OF

French and Francophone Philosophy
REV U DE L A

philosophie française et de langue française

\title{
Jean Améry: Commemoration and Comparative Engagement
}

Jeffrey Bernstein

Journal of French and Francophone Philosophy - Revue de la philosophie française et de langue française, Vol XXIV, No 3 (2016) 1-2.

\author{
Vol XXIV, No 3 (2016) \\ ISSN 1936-6280 (print) \\ ISSN 2155-1162 (online) \\ DOI $10.5195 /$ jffp. 2016.783 \\ www.jffp.org
}

\section{(c) EY-NC-ND}

This work is licensed under a Creative Commons Attribution-Noncommercial-No Derivative Works 3.0 United States License.

\section{ULIS D-Sulle}

This journal is operated by the University Library System of the University of Pittsburgh as part of its D-Scribe Digital Publishing Program, and is co-sponsored by the University of Pittsburgh Press 


\title{
Jean Améry
}

\section{Commemoration and Comparative Engagement}

\author{
Jeffrey Bernstein \\ College of the Holy Cross
}

2016 marks the 50 th Anniversary of the publication of Jean Améry's collection of essays dealing with his experiences at (and in the aftermath of) Auschwitz entitled Jenseits von Schuld und Sühne: Bewältigungsversuche eines Überwältigten. Translated into English as At The Mind's Limits: Contemplations By A Survivor On Auschwitz And Its Realities, Améry's collection immediately set a standard for philosophical accounts of the camps that even today remains unchanged. More uncompromising than the texts of Wiesenthal, Levi, Borowski, and Wiesel, Améry's collection philosophically explores the extreme limit of the survivor's experience in the camps as well as the ensuing trauma of living in its wake.

Améry's text is not simply an account of life in the camps (in the manner of Wiesel). It is, rather, a phenomenological account of that experience and its aftermath. Its chapters "At the Mind's Limits," "Torture," "How Much Home Does A Person Need?", "Resentments," and "On The Necessity [or as I render it, "Duress"] and Impossibility of Being a Jew," provide a detailed analysis of Améry's situation as it becomes impacted by questions concerning the value of life in the camps, torture and pain, home and homelessness, resentment and forgiveness, and Judaism (among others). It can, in fact, plausibly be argued that At The Mind's Limits is the single most important philosophical text dealing with the Shoah (certainly by an actual survivor).

Even though Améry (originally Hans Meyer) was born in Austria, his experiences led him not only to adopt a French pen name, but also to identify with French culture, literature and thought more broadly. His internal philosophical interlocutors included Sartre, Jankélévitch, and Memmi, among others. Similarly, his works take critical aim at thinkers such as Neher, Levi-Strauss, and Foucault. In keeping with this aspect of his work and life, many of the contributors collected herein explore conversations between Améry and the work of Sartre, Camus, and Levinas. Because the 
themes of Améry's essays are important for such a wide range of contemporary thought, some contributors have found natural convergences with other thinkers as well-for example, Kant, Cohen, Adorno, Arendt, Peter Sloterdijk, Edith Wyschogrod, and Jackie Robinson. But whether the contributions deal with Améry's reflections on torture (Ferber, Ben-Shai), aging (Drouillard, Stauffer), revolt and dignity (Feuer, Anderson), home and world (Shuster, O'Byrne), or what it means to be a Jew in the light of the Shoah (Erlewine, Achtenberg, Benjamin, Bernstein), all attest to the enduring power and provocation of his writings. A world in which Améry's writings are taken into account is a world in which solidarity with the defeated (or in Levi's term, the "drowned") becomes a meaningful action. The contributors to this journal issue show, each in their own way, what this possibility looks like. 